\title{
THE APPLICATION OF PHYSIOGNOMY FOR COMIC CHARACTER DEVELOPMENT IN “MENJELAJAH NEGERI REMPAH” COMIC
}

\author{
Ahmad Faisal Choiril Anam Fathoni ${ }^{1 *}$; Patricia Renata ${ }^{2}$; Dermawan Syamsuddin ${ }^{3}$; \\ Satrya Mahardhika ${ }^{4}$ \\ ${ }^{1-4}$ Animation Program, Visual Communication Department, School of Design, Bina Nusantara University \\ Jl. K. H. Syahdan No. 9, Palmerah, Jakarta Barat 11480, Indonesia \\ 1anam.fathoni@binus.ac.id; ${ }^{2}$ patricia.renata@binus.ac.id; ${ }^{3}$ deddy_syam@binus.ac.id; ${ }^{4}$ satrya.mahardhika@binus.ac.id
}

Received: $14^{\text {th }}$ December 2020/ Revised: $04^{\text {th }}$ March 2021/ Accepted: $30^{\text {th }}$ March 2021

\begin{abstract}
How to Cite: Fathoni, A. F. C. A., Renata, P., Syamsuddin, D., \& Mahardhika, S. (2021). The application of physiognomy for comic character development in "Menjelajah Negeri Rempah" comic. Humaniora, 12(2), 99-106.

https://doi.org/10.21512/humaniora.v12i2.6862
\end{abstract}

\begin{abstract}
The research aimed to document the journey of character development in 'Menjelajah Negeri Rempah' comic with physiognomy studies. Indonesia was known as a maritime country that had emerged as one of the largest producers of spices in the last centuries. Unfortunately, younger generations of Indonesia lacked the knowledge of spices. This was one of the reasons why young Indonesians were less concerned with the existence of spices. Several things had been done by the government to socialize the glory of spices in the past so that spices would return to their glory in the future. The researchers who were involved in the teaching and learning process in the Visual Communication Design department wished to take part in this effort through comics to help the government spread knowledge to the younger generation through visual languages they liked without appearing patronizing. In creating this comic, one of the priorities was in the development of characters, which needed to be designed in such a way so that the characters were more easily recognized, and the stories came alive. To strengthen the character, it applied physiognomy in the development of the character designs contained in the comic. It used the design thinking process as a continuously applied design method in this character creation development. It consisted of define, research, ideation, prototype, select, implementation, and learn. The research results are in the form of the comic 'Menjelajah Negeri Rempah', which aims to introduce Spice Route as this country's potential instead of the more famous Silk Road. The result of the research still requires additional data, considering that in the process of making comics, apart from building a relatable character, a strong story is also needed.
\end{abstract}

Keywords: character design, comic character, physiognomy, spice route, face reading

\section{INTRODUCTION}

Indonesia or Nusantara is known as a maritime spice-producing country. Centuries ago, spices were traded all over the world and became an important commodity that was able to provoke European exploration and colonization of the occupied areas. These Indonesian treasures, which are still sought after by those countries, still exist today, and with proper management, can have enormous potential. Unfortunately, the appreciation for Indonesia's past glory is still lacking. It is especially true for the younger generation who hopes to bring Indonesia in a better direction. As stated by Rahmat (2020), the young generation is currently lacking in knowledge about spices. It is one of the reasons why young Indonesians are less concerned with the existence of spices.

Appreciation and concern for the glory and history of spices in the past need to be cultivated, especially for the young generations. They have the furthest time span from the time when spices were the substance that was highly sought after by a handful of countries so that they understand how the spice route played a crucial role in the development of Indonesia in the past, present, and future. The government has also attempted to increase the younger generation's appreciation of the history of this spice route. It does not just revive back the glory but also make sure that 
the importance of the Spice Route is to be truly felt by all levels of society.

According to Widyanuratikah (2021), the Directorate General of Culture of the Ministry of Education and Culture will bring back the issue on the history of the spice route by making it the main focus for the 2021 program and targeting the spice route to be nominated by UNESCO as a cultural heritage by 2024. Widyanuratikah (2021) has also added that the government also put forth a few programs targeted at young generations. The Culture Development and Utilization Division held competitions for teenagers such as poster making, animation, comics related to the history of the spice route. As an effort to put forth the knowledge of the spice route, several media can be used, as Nusantara's Spice Route glory was much more widely known in the past than the Silk Road, yet it is much less spoken about. One of the most effective media is comic form. It is easily approachable at any age, thereby helping them open access to more comprehensive knowledge about the spices in Nusantara.

Zagkotas (2019) has mentioned that comics are an effective medium to convey the history and avoid the phenomenon mentioned by Kasidou that history is a stupid and boring lesson full of names and dates. The wish is that through comics, history can be much more interesting and still convey the message the country wants to put forth without being patronizing. Through this media, the researchers that are consisted of three lecturers and a comic artist student collaborate in the creation of this comic. In this comic, the researchers intend to create a story that can be a bridge towards the appreciation of the richness of spices in Indonesia. This research aims to document the character creation process in this comic using design thinking its production process using the design thinking process (Ambrose, 2019).

The researchers put four child characters in this comic, namely Ale, Beta, Caca, and Dio, as the main characters. These four children represent different personalities. The first character, named Gelfara Sihasale or Ale, comes from Maluku. He is an Indonesian-Portuguese mixed descent child that has a melancholic-choleric personality, obsessivecompulsive disorder, bossy, goal-oriented, irritable, good at art, and ambitious. The second character is Beta Paramula, from Kalimantan; this phlegmaticmelancholic character is the smartest figure in this group, a bookworm, introvert if talking with strangers, and a perfectionist. Meanwhile, Chandra Cahyaningwang from Solo, who is usually called Caca, is a phlegmatic-sanguine person who actually is meek and peace-loving and tends to reconcile when her friends are disputing. The last character is Sagara Pramudio or Dio from Jakarta, who has a sanguinecholeric personality, tends to be chatty, assertive, often has problems with Ale, a brag person that always happy.

\section{METHODS}

The research applies a design thinking process as the method to develop characters in this comic. Based on Ambrose (2019), there are seven steps to identify: define, research, ideation, prototype, select, implement, and learn. In step one, define, the design problem and the target audience need to be defined. Correct understanding of the problem and its boundaries allows for more precise solutions. Figure 1 shows the design thinking stages.

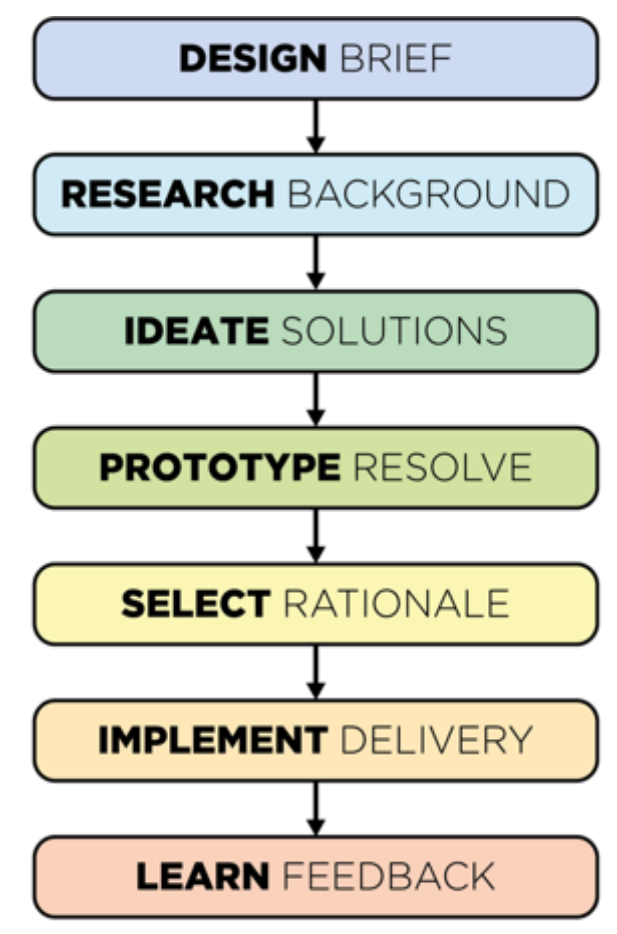

Figure 1 Design Thinking Stages (Ambrose, 2019)

Roth et al. (2020) have mentioned that through their hypotheses, 160 students participated in 62 innovation projects for companies and concluded that design thinking is beneficial for projects that are intended to create innovation.

In the process of character creation and development, the researchers go through six out of seven stages of design thinking mentioned in Ambrose (2019). The progress has not yet reached the stage of 'learn' because this phase requires feedback, while this comic has not been published to the masses. In the stage 'define', as designers, the researchers try to understand the need of the target market so that it can adapt the way the researchers create comic content so that this comic can be the media for the young generation to easily understand the past glory in society by narrating the history of spices, one of the greatest strengths in the past, present, and future.

The continuation phase of 'define' is the 'research'. This stage determines what is required for the project to be successful. The research is continued by opening some literature related to the history of 
spices and the exploration of Europeans in the search for spices. It is found out how this nation holds a very valuable treasure and is sought after by European countries so much at the time. They put all their means to get, whether gambling, blood sacrifice or even deaths in war all for spices, which have an abundance of this country.

The research stage reviews information such as how to tell history in an exciting way to target. In this phase, observations are also carried out using secondary research sources related to making interesting character designs and having relatable interactions. As Horton (2000) has said, stories can be divided into two types: plot-centered stories and character-driven stories; in this comic, the researchers use the character-driven story approach.

When the research process has been carried out, it is followed by the ideation phase. It is the stage where the motivation and needs of the audience are identified, and ideas are generated to fulfill them. One of which can be done through brainstorming and mind mapping. The ideation results are then used as a prototype to see the results of the execution of these ideas, which are then shown to the targeted respondent sampling before being presented to the client. From several prototypes made, a 'select' process is carried out to see the priority of the proposed solution in terms of design objectives.

After all these processes have been carried out, the final stage is in the 'implementation' process by applying the selected design into the comic. This stage is the last process of implementation to developing the characters in this comic creation process.

To continue the research, the researchers need to do the last step in the design thinking process, 'learning'. This learning phase is needed to seek feedback and determine whether the solution has met the brief's objectives so that it can be further identified for future improvements.

\section{RESULTS AND DISCUSSIONS}

Nusantara was known for centuries as one of the largest spices-producing countries. There are many spices that have become the strength of this country, such as pepper, cloves, cardamom, turmeric, ginger, cinnamon, camphor, mace, and nutmeg. Based on Deryanti, Zuhud, and Soekmadi (2014), the nutmeg plant was first introduced to Java during Marco polo's trip to China, which passed through the island of Java between 1271 and 1295 .

Van Ittersum (2016) has mentioned that on Great Banda, more nutmeg trees rose than on all the other archipelago islands combined. Nutmeg was later extended to Sumatra and other parts of Indonesia as well. While mentioned by Pakpahan, Bermawie, and Wiratno (2020), the attraction of nutmeg for Indonesia has a greater role in Indonesian history.

Nutmeg originated in Banda Island. In the old days, it was the intention of all nations to come to the Banda Islands for prosperity. The inhabitants and culture of this region have been changed through colonialization. If, in the past, nutmeg was a sign of colonialism, then in the future, nutmeg is created as a symbol of global cultural friendships.

This glory and greatness need to be known to all Indonesian people, especially the younger generation, who are the heirs of this nation's treasure. With their knowledge of the value for this country's assets in the eyes of other countries, appreciation for spices can be raised. In an effort to provide this understanding to the younger generation, the Ministry of Education and Culture is holding an event that is expected to motivate artists and designers to participate according to their skills.

Indonesians are a species of storytelling. Boyd (2017) has stated that Indonesian ancestors had become very dependent on one another, at least by exchanging knowledge in mimetic and prelinguistic ways. Meanwhile, according to Nairat, Nordahl, and Dahlstedt (2020), comics as a storytelling medium are especially well suited to generative approaches due to their open understanding. Nairat, Nordahl, and Dahlstedt (2020) have also said that the simplicity of graphic representation has a great influence on the visual rhetoric of the comics created. This could be enhanced by adding more comic features such as various panel layouts, better encapsulation, and cinematic views.

The Ministry of Education and Culture is very supportive of any effort to spread the knowledge of the spice route. As an effort by the creators of this comic, the researchers wish to participate in spreading more knowledge of the spice route in the field they thrive in. Because this comic is based on history, the researchers try to write this story in narrative order. To make this comic more interesting, the researchers follow a more character-driven story approach.

This approach requires character study in order to evoke the audience's emotions in response to the characters. Just like, Greenberg (2018) has explained that Blackton also implements the fundamental building blocks of animated character designs that are traditional to this day; designs that focus on an emotional, universal heart overlaid with culturespecific objects. In addition, Yi (2017) has mentioned that background information on the psychological and sociological components is essential to the character's design and that specific areas of each dimension are organized for the visual representation of the character.

As stated by Brown et al. (2019), Protagonism that a more protagonist-driven approach to writing can focus on character processes, especially the central protagonist's psychological complexities. Based on Nielsen (2002), a story should have a powerful central character with ambitions and aspirations that need fulfillment throughout the plot, thereby resembling a character-driven story. In creating comics that are attractive to children aged 7-12 years, a character design that is easily recognized and able to display the character's personality is needed. The features of these 
characters should represent what kind of characters are displayed to make it easier for children to relate to the story. To strengthen the emotional side of the characters in this comic, the researchers use physiognomy to strengthen the character's personalities and traits. Physiognomy is the science of reading a person's character through the features found on each person's face. The author uses it as a bridge that connects certain facial shapes with certain personalities or habits. With physiognomy, the relationship between face shape and character becomes more related.

The method used is design thinking. Ambrose (2019) has described seven design thinking steps to identify: define, research, ideation, prototype, select, implement, and learn. Implementing the design thinking process in making comic characters is begun with the first phase, namely define. This process is trying to understand what the client needs, in this case, the Ministry of National Education, which currently requires the media to bring the next generation to know the richness of spices in the archipelago and hopefully love it more. Currently, the appreciation from adults, especially children, about the spice route and its function is still very little appreciated.

The second phase of the steps described by Ambrose (2019) is research. Based on the brief, and the researchers choose a target for children aged 7-12 years, then do some research related to characters in comics that also the target market at that age. In some comics that are currently reaching their peaks of popularity, such as Tahilalats (Figure 2) with 4,2 million followers, Dalang Pelo (Figure 3) with 3,6 million followers, Si Nopal (Figure 4) with 2,1 million followers, the researchers try to see the dominance of the face shape, the lines used, the shading that is often applied. It turns out that most of the comics tend to use thin outlines (not implied lines), rarely using shading. While most of the comics tend to use primary colors that are saturated down.

From some of these comics, the researchers try to use the same approach in creating alternatives in the next design thinking step, the ideation that uses brainstorming. In this step, the researchers try several design alternatives based on previous comic character research that explore many options of lines, shapes, and color. Figure 5 shows Ale character brainstorming, Figure 6 shows Beta character brainstorming, Figure 7 shows Caca character brainstorming, and Figure 8 shows Dio character brainstorming.

To make the story stronger, the researchers chose to use a character-driven story approach. It applies the theory of four personalities to make the interactions between characters more opposites so that it is easier to create conflicts, which are the essence of a story. According to Setyadi, Harsono, and Wasista (2015), the Greco-Roman model uses relative

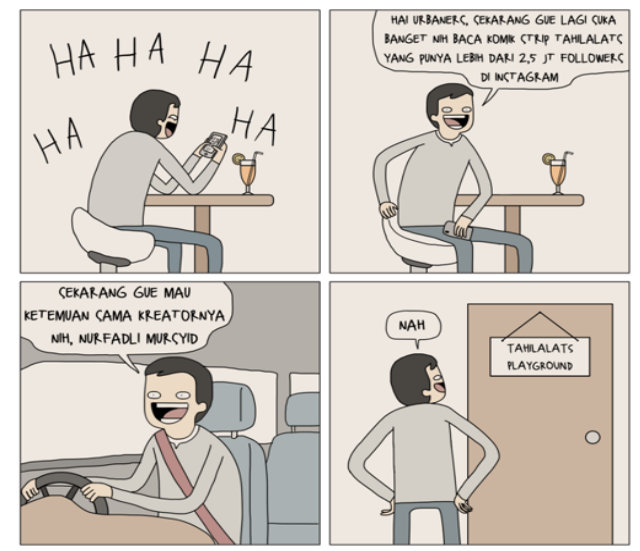

Figure 2 Tahilalats Comic

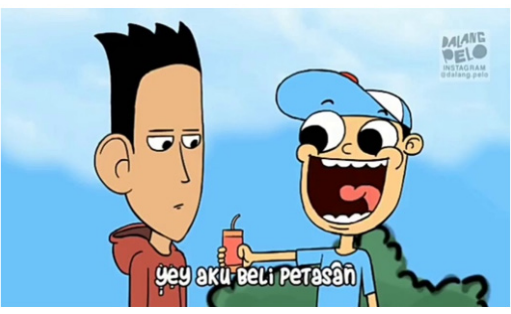

Figure 3 Dalang Pelo Comic

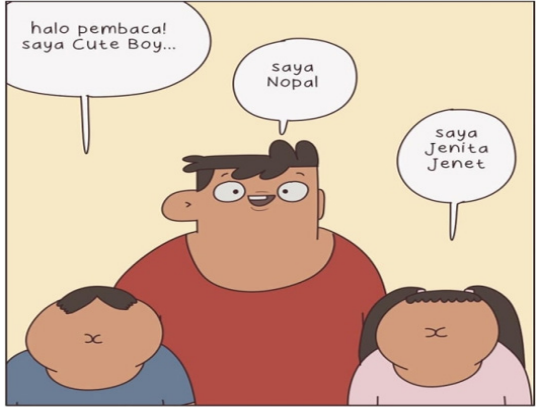

Figure 4 Si Nopal Comic 

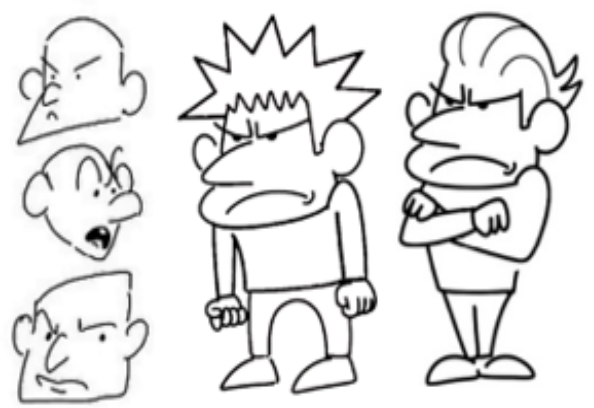

Figure 5 Ale Character Brainstorming
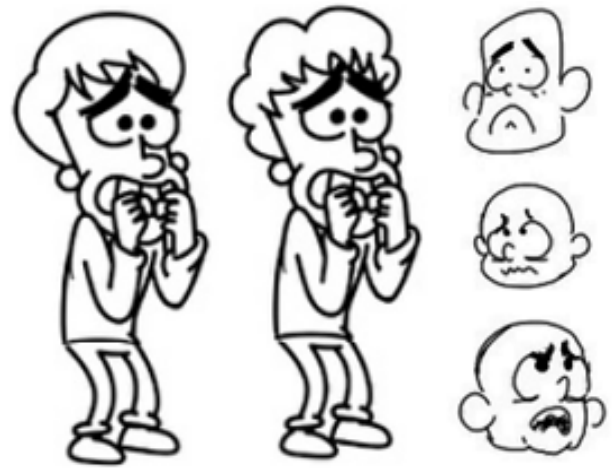

Figure 6 Beta Character Brainstorming

amounts of various bodily fluids to assess four types of temperaments: melancholic, choleric, sanguine, and phlegmatic.

Based on Engler B in Yosua et al. (2014), Hippocrates (circa 400 B.C.) and Galen (circa 200 A.D.), two Greek doctors, recommended the presence of four basic personality characteristics: melancholics, phlegmatic, choleric, and sanguine. Melancholic personality trait concept is characterized by several facets such as moody, anxious, rigid, sober, pessimistic, reserved, unsociable, and quiet. While passive, careful, thoughtful, quiet, regulated, reliable, even-tempered, and calm are all characteristics of phlegmatic. The other personality, choleric, is defined as perplexing, anxious, aggressive, volatile, changeable, imprudent, optimistic, and complex. The last personality, sanguine, is described as sociable, outgoing, talkative, responsive, easygoing, enthusiastic, carefree, and leaderlike.

The researchers try to have these four personality types equally. Because the main characters consist of four people, each character represents a primary personality and a secondary personality. Ale is a choleric-melancholic character, which means he has the two personalities above but is stronger in the first personality, choleric. Another character is Beta, the smartest character in this comic; he has a melancholic-phlegmatic personality. One female character here is Caca, who is a phlegmatic-sanguine character. Meanwhile, the final main character is Dio, who is a sanguine-choleric.

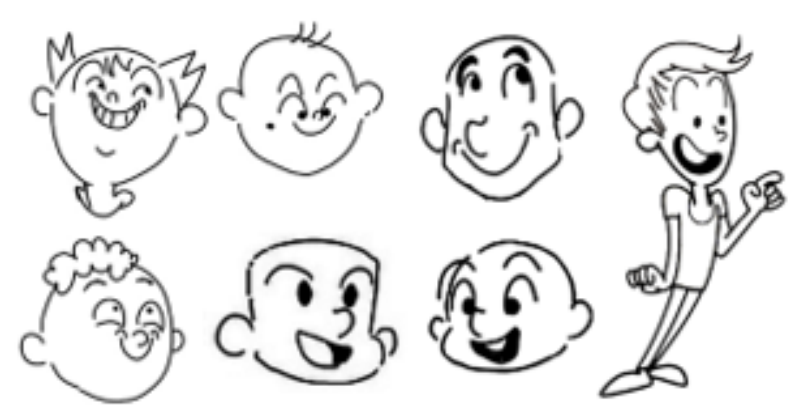

Figure 7 Caca Character Brainstorming
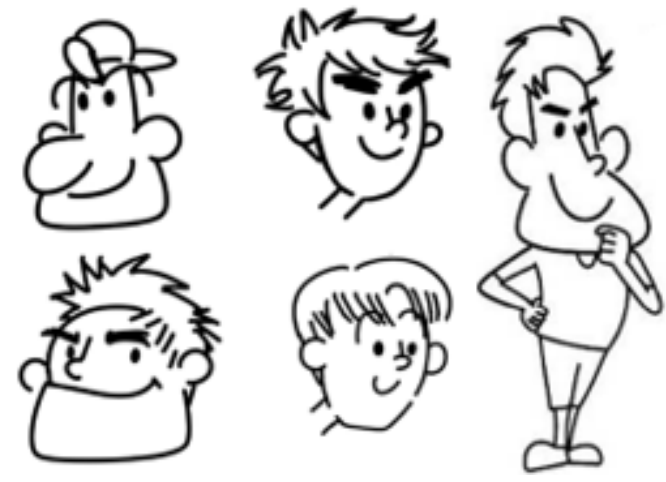

Figure 8 Dio Character Brainstorming

In developing these comic characters, the researchers use a physiognomy approach or the science of reading faces to get closer to the character traits and personalities with the visual form of these characters. Physiognomy is the science of reading a person's character and personality by looking at his/her facial features. According to Abulaban, Muzher, and Thawabieh (2018), it is possible to judge personality rapidly and reliably and with considerable precision from the characteristics of a person's body based on the concepts of physiognomy.

Jia, Tian, and Fan (2019) have stated that Edmonds JM explains in his book, The Characters of Theophrastus, that since the Greek philosopher Theophrastus (371 B.C. - 287 B.C.), people have been keen on studying personality, which is also known with physiognomy. Based on Tickle (2003), this study has been around since 2.700 years ago. There are various applications in various parts of the world, both in eastern areas such as in China, India, Arabia, or western regions as popularized by Shakespeare, Milton, Dryden, and later towards the end of the $18^{\text {th }}$ century, Johaness Caspar Lavater, through her book, Essay in Physiognomy, undertook a comprehensive project to classify facial features as well as mental abilities and tendencies. Around the 1930s, Edward Jones used Lavater's research and looked at 200 different facial features and then narrowed them down to 68 traits. This research was continued by Robert Whiteside around the 1950-1960s. The researchers use the study of physiognomy in developing the designs, 
especially in the form of the characters' faces in this comic. By using physiognomy in developing character designs, the researchers can more easily determine which shape will use according to the personality and traits.

As mentioned by Liu et al. (2017), statistical findings show a clear connection between facial structures and personality traits. Physiognomy has been used as one of the key methods in evaluating candidates by various vocational institutes, such as the Merton Institute, which provides services to companies including AT\&T. Therefore, one of the most intuitive ways to represent a person's personality is through physiognomy.

One of the facial features attached to a phlegmatic person who usually avoids conflict is the thin face shape. In terms of comparison, it tends to be taller than wide. His sensitive character is represented by the soft hair shape, while the choice of the wideeye shape brings out the innocence of her character. Meanwhile, to enrich the message from the Beta character, the researchers create the Ale character, a Portuguese descent boy from the Ternate area. Although both are melancholy, Ale's character is dominated by a choleric personality who tends to be more intimidating.

For this reason, a wide-face character is chosen because this kind of facial feature more often appears in aggressive or intimidating characters. Just as Welker et al. (2015) have mentioned that facial-width-toheight ratio (FWHR), or the ratio of a face's width to the vertical distance between the upper lip to the midbrow, is positively related to antisocial behavior in men, including aggression, unethical behavior, expression of prejudice, and the absence of reciprocity especially when individuals are low in social status. Not only do wider-faced men have these characteristics, but high FWHR men are perceived as being more aggressive, more dominant, and less trustworthy by others.

Even though the character tends to be oppressive, he will give much enthusiasm to his friends in appreciating spices in Indonesia at the end of the story. As the wider face shape is more likely to be found in people who have a choleric or dominant personality, on the other hand, the opposite character or phlegmatic personality needs to be made thinner or taller.

After ideation, the next design thinking step is the prototype. At this step, the researchers use the best option in line, shape and color application, and combine it together. It is started with sketches of each character with several alternatives in the form of sketches and several poses to make it easier to see when in the comic later. This prototyping phase is the part that replicates how these characters interact with each other in their adventure in the comic. In this phase, some changes are made to make the character more attractive and more in line with the target segment. Figure 9 shows the sketch prototyping.

At first, all of the characters are male; therefore, the researchers change the third character, Caca, becomes a female character at this prototype step to make the design more variable. In this step as well, Ale's face is changed to be more childish. To present a melancholy choleric impression in Ale's character, there are several lines on his face that make him look older than his friends.

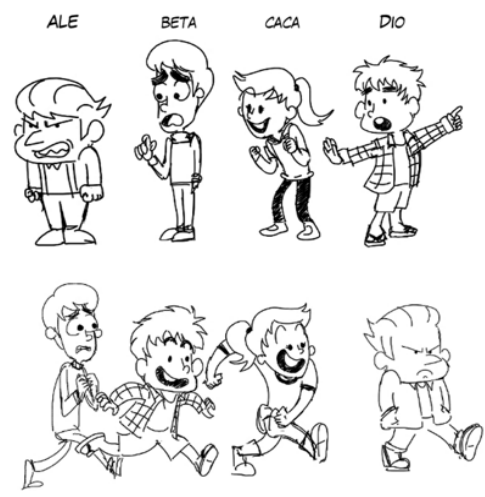

Figure 9 Sketch Prototyping

At first, all of the characters are male; therefore, the researchers change the third character, Caca, becomes a female character at this prototype step to make the design more variable. In this step as well, Ale's face is changed to be more childish. To present a melancholy choleric impression in Ale's character, there are several lines on his face that make him look older than his friends.

The next step in design thinking is 'select' (Figure 10); it happens when entering the color phase. The researchers are interested in varying their origins, such as the Ale character (Gelfara Sihasale), a Portuguese descent boy from the Ternate area; the researchers make his skin color more reddish pink. Meanwhile, Beta Paramula, who is descended from Kalimantan, tends to have the lightest skin because most Dayaks have a lighter skin color. For Chandra Cahyaningwang or Caca character, the researchers make her as Javanese with Chinese descent so that his skin color tends to be more yellow. The last character, Dio (Sagara Pramudio), is a Jakarta child of Javanese descent. Because he is an active child outside, he has the darkest skin compared to other kids.

As the characters created here already have specific personalities and traits, the next step is 'implement' (Figure 11) by adding a story that can convey the purpose of this comic, which is to provide knowledge about the history of spices in a way that is not too patronizing. For that, it is needed to create comics that not only try to tell the history of spices in the Nusantara but also want to make this comic relatable to children, who are the main target audience for this comic. So, it uses an approach from everyday life that allows it to be associated with spices. In making this comic script, the researchers try to start not with history, which is not too attractive for children. However, it begins with problems that arise in children's lives, such as abdominal pain, which 
sometimes occurs due to first menstrual or menstrual phases, which can be a torturous experience, or a tendency to have the sleeping problem as their sleeping patterns is by the habit of using gadgets at night.

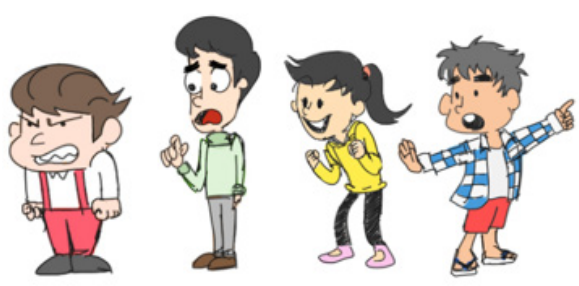

Figure 10 Selecting Color

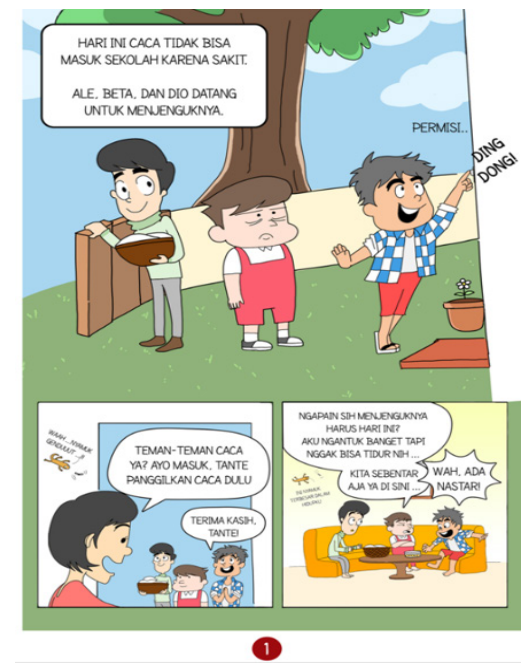

Figure 11 Implementing in Comic

This scene begins with Ale, Beta, and Dio visit Caca's house as she misses school due to illness. These three characters, Ale, Beta, and Dio, make discussions with Caca to comfort her as she gets a stomachache. Ale also complains that last night he could not sleep, and the next day he visits him feeling forced. Then Beta tries to provide a solution using his understanding of spices as a remedy for the two problems faced by both Caca and Dio.

The emergence of this solution arises appreciation from other friends to listen to the history of spices in the archipelago, then focus on things related to spices that provoked them. This approach is actually also applied to the audience who reads this comic. By opening a story with things that are not related to history, it is hoped that a barrier to starting reading is expected because history lessons can be more adapted.

After implement step, the last step in design thinking is 'learning'. Since this learning phase requires sufficient feedback from readers, the research requires further exploration of this creation process.

From here, the researchers need to evaluate the comics so that the greatest goal of this comic can be achieved, which becomes a bridge for the latest generation to the importance of realizing the power of this nation's spices so that they can have a strong appreciation of the wealth of this country. The other research that still needs to be continued is to pay attention to other aspects such as stories, material completeness, and visual execution that can be learned from the feedback from the readers.

\section{CONCLUSIONS}

In the process of making comics, several things need to be considered. One of them is character creation. Character development in comics will be easier by using facial reading or physiognomy to get a more unique character and represents the characters.

The research focuses on the study of character development in the comic Menjelajah Negeri Rempah, using physiognomy or facial reading to strengthen their personality. To strengthen the message's impact to be conveyed and reach the targeted segment better, further research is needed, especially those related to other elements such as stories, material completeness, and visual execution that can be learned from the readers of this comic.

The research uses design thinking as a method to develop character, which consists of define, research, ideation, prototype, select, implement, and learn. Physiognomy is proven to make it easier for the researchers to carry out the execution in choosing what kind of face is appropriate to describe the personality or traits in making comic characters.

The direct implication of the research is the creation of a comic containing the history and information of the spice route. Through the design thinking stages process, this comic has the potential to contribute in conveying history and knowledge of the spice route in a fun way and in a language that is easier to accept without having to patronize the readers.

\section{REFERENCES}

Abulaban, M. L., Muzher, S. S., \& Thawabieh, A. M. (2018). The relationship between predicting personality using physiognomy and through using personality scale. World Journal of Social Science, 5(2), 22-39. http://dx.doi.org/10.5430/wjss.v5n2p22.

Ambrose, G. (2019). Design thinking for visual communication (basics design) (reprint). US: Bloomsbury Visual Arts.

Boyd, B. (2017). The evolution of stories: From mimesis to language, from fact to fiction. WIREs Cognitive Science, 9(1), 1-16. https://doi.org/10.1002/ wcs. 1444.

Brown, S., Berry, M., Dawes, E., Hughes, A., \& Tu, C. (2019). Character mediation of story generation via protagonist insertion. Journal of Cognitive Psychology, 31(3), 326-342. https://doi.org/10.1080 /20445911.2019.1624367.

Deryanti, T., Zuhud, A.M., E., \& Soekmadi, R. (2014). Konservasi pala (myristica fragrans houtt): Suatu 
analisis tri stimulus amar pro-konservasi kasus di kabupaten Bogor. Media Konservasi, 19(1), 47-56. https://doi.org/10.29244/medkon.19.1.

Greenberg, R. (2018). How animation won over the lightning sketch: Re-evaluating humorous phases of funny faces. Animation, 13(2), 162-174. https://doi. org/10.1177/1746847718783641.

Horton,A. (2000). Writing the character-centered screenplay ( $1^{\text {st }}$ Ed.). California: University of California Press. Retrieved from https://www.amazon.com/ Writing-Character-Centered-Screenplay-UpdatedExpanded/dp/0520221656.

Jia, X., Tian, W., \& Fan, Y. (2019). Physiognomy in new era: A survey of automatic personality prediction based on facial image. International Conference on Internet of Things as a Service, 271, 12-29. https:// doi.org/10.1007/978-3-030-14657-3_2.

Liu, Y., Huang, M. L., Huang, W., \& Liang, J. (2017). A physiognomy based method for facial feature extraction and recognition. Journal of Visual Languages and Computing, 43, 103-109. https://doi. org/10.1016/j.jvlc.2017.09.006.

Nairat, M., Nordahl, M., \& Dahlstedt, P. (2020). Generative comics: A character evolution approach for creating fictional comics. Digital Creativity, 31(4), 284-301. https://doi.org/10.1080/14626268.2020.1818584.

Nielsen, L. (2002). From user to character: An investigation into user-descriptions in scenarios. Proceedings of the $4^{\text {th }}$ Conference on Designing Interactive Systems: Processes, Practices, Methods, and Techniques. London, England. pp 99-104. https:// doi.org/10.1145/778712.778729.

Pakpahan, A., Bermawie, N., \& Wiratno. (2020). Indonesian's nutmeg for the world, synergizing consumers need while increasing farmer's welfare. International Conference on Sustainable Plantation, 418, 1-8. https://doi.org/10.1088/17551315/418/1/012007.

Rahmat, R. (2020). Minim informasi, penyebab kaum muda tidak cinta rempah. Retrieved from rri.co.id.

Roth, K., Globocnik, D., Rau, C., \& Neyer, A. K. (2020). Living up to the expectations: The effect of design thinking on project success. Creativity and Innovation Management, 29, 667-684. https://doi. org/10.1111/caim.12408.

Setyadi, A., Harsono, T., \& Wasista, S. (2015). Human character recognition application based on facial feature using face detection. International Electronics Symposium (IES). pp 263-267. https:// doi.org/10.1109/ELECSYM.2015.7380852.

Tickle, N. R. (2003). You can read a face like a book: How reading faces helps you succeed in business and relationships. California: Daniel's Pub.

Van Ittersum, M. J. (2016). History of European ideas debating natural law in the Banda Islands: A case study in Anglo-Dutch imperial competition in the East Indies, 1609-1621. History of European Ideas, 42(4), 459-501. https://doi.org/10.1080/01916599.2 015.1101216.

Welker, K. M., Goetz, S. M. M., Galicia, S., Liphardt, J., \& Carré, J. M. (2015). An examination of the associations between facial structure, aggressive behavior, and performance in the 2010 world cup association football players. Adaptive Human Behavior and Physiology, 1(1), 17-29. https://doi. org/10.1007/s40750-014-0003-3.

Widyanuratikah, I. (2021). Kemendikbud buat peta sejarah jalur rempah. Retrieved from https://www. republika.co.id/berita/qmrnnx368/kemendikbudbuat-peta-sejarah-jalur-rempah.

Yi, J. H. (2017). The structure of extracting a character's appearance components. International Journal of Arts and Technology, 10(1), 1-26. http://dx.doi. org/10.1504/IJART.2017.083900.

Yosua, I., Thomas, O., Islamia, I., \& Chang, S. (2014). The differences in subjective well-being among four personality trait combinations. International Conference on Education, Psychology, and Social Sciences. Taipei, Taiwan.

Zagkotas, V. (2019). Are comic books appropriate for teaching History? Three suggestions for Greek primary education. Education 3-13, 47(3), 358-365. https://doi.org/10.1080/03004279.2018.1452955. 